\title{
ASSESSING THE SERVICE QUALITY \\ AND CUSTOMER SATISFACTION RELATIONSHIP IN THE CROATIAN MUSEUM SECTOR
}

\author{
Suzana Marković \\ Sanja Raspor Janković
}

DOI: https://doi.org/10.31410/tmt.2019.223

\begin{abstract}
The main purpose of this study was to discuss the impact of perceived service quality dimensions on customer satisfaction in the museum sector in Croatia. The study was conducted using a 24-item questionnaire, based on the modified HISTOQUAL model (Frochot \& Hughes, 2000; Hui-Ying $\&$ Chao-Chien, 2008; Martin-Ruiz et al., 2010). The questionnaires were distributed to visitors of the Krapina Neanderthal Museum (Croatia). Factor analysis identified five dimensions of perceived museum service quality, namely "tangibles", "accessibility", "exhibition presentation", "empathy" and "communication". In addition, multiple regression analysis showed that the identified factors have a significant and positive effect on overall customer satisfaction. These results indicate that museum service quality is indeed a significant predictor of museum visitor satisfaction. Thus, improving museum service quality results in higher satisfaction levels of museum visitors. The present study contributes to the existing literature on the relationship between service quality dimensions and customer satisfaction in the museum sector, reporting the findings from South Central Europe.
\end{abstract}

Keywords: Service quality, HISTOQUAL, Customer Satisfaction, Statistical Analysis, Museum, Croatia.

\section{INTRODUCTION}

$\mathrm{M}$ useums have gained an important role in tourist destinations as one of a destination's elements that can attract both domestic and foreign visitors, as well as local residents. As museums are becoming more market-oriented, they should focus not only on their product (e.g. exhibitions, financial resources, educational programmes, facilities, heritage features, etc.), but should also pay more attention to their visitors' opinions and perceptions, as well.

Having in mind the competition in the field of tourist attractions and the ability of tourist attractions to produce benefits for both the local community and the tourist destination, it is important to investigate what visitors think of museum services and what makes them feel satisfied with their museum visit. According to Harrison and Shaw (2004), service quality plays a key role in increasing positive visitor satisfaction, which in turn results in favourable intentions toward the idea of a museum as a destination.

Thus, this study has several research objectives. The first objective is to identify the dimensions of museum service quality as perceived by museum visitors. The second is to examine the relationship between perceived museum service quality dimensions and museum visitor satisfaction in the context of a continental tourist destination.

\footnotetext{
1 University of Rijeka, Faculty of Tourism and Hospitality Management Opatija, Primorska 42, P.O. Box 97, 51410 Opatija, Croatia

2 Polytechnic of Rijeka, Trpimirova 2/V, 51000 Rijeka, Croatia
} 


\section{THEORETICAL OVERVIEW OF THE MAIN RESEARCH CONCEPTS}

In order to measure service quality in a heritage context, including museums, Frochot and Hughes (2000) proposed a model called HISTOQUAL. Results of model testing revealed that service quality in historic properties consists of five dimensions, namely, responsiveness (staff efficiency and the ability to recognise customer needs), tangibles (property environment (interior and exterior), such as cleanliness, authenticity, and attractiveness), communication, (quality and detail of the information provided), consumables (additional services such as restaurants and shops), and empathy (willingness to take into consideration the needs of children and less able visitors).

A review of the literature implies that several authors have listed the basic elements of museum service quality, similar to the HISTOQUL dimensions. Gilmore and Rentschler (2002) revealed that education, accessibility, communication, relevance and frequency of special exhibitions are important elements for delivering service quality in museums. Phaswana-Mafuya and Haydam (2005) suggested that service quality in museums comprises accessibility, safety, cleanliness, and providing information. Mey and Muhamad (2010) concluded that perceived service quality in museums includes a museum's accessibility, information sources, quality of displays/exhibitions, customer services, amenities and facilities, and pricing of souvenirs, food and beverages sold in the museum.

In addition, Radder et al. (2011) consider that the overall quality of a museum depends on the quality of its products, quality of its services and quality of the visiting experience. Similarly, Pop and Borza (2016) propose that factors influencing museum quality can be grouped into three categories: factors determining museum quality from the clients'/visitors' point of view, from the staff's point of view, and factors that influence museum quality irrespective of the visitors' or staff's perception.

It can be concluded that museum service quality is a complex concept that refers to several aspects of the museum experience. It relates to museum exhibits and their presentation, as well as to personnel competence and empathy.

Customer satisfaction has usually been defined as a post-consumption evaluative judgement (Fornell, 1992; Oliver, 1997). In addition, Oliver (1997) defined customer satisfaction as a judgement that a product or service provides a pleasurable level of consumption-related fulfilment.

Kozak and Rimmington (2000) indicated that visitor satisfaction has been measured by the summation of visitor evaluation of destination attributes.

Several studies have highlighted the positive relationship between service quality and customer satisfaction in a museum context. Nowacki (2005) reported that exhibition features (e.g. aesthetics, theme, and the way an exhibition is arranged) and easy access for the elderly and disabled are significantly correlated with visitor satisfaction in museums in Poland. Radder and Han (2013) argued that perceived quality positively affected visitor satisfaction in South African heritage museums. The research results of $\mathrm{Wu}$ and $\mathrm{Li}$ (2015) also confirmed that overall service quality positively influenced visitor satisfaction in museums in Macau. Duantrakoonsil and Reid (2017) explored the impact of service quality on customer satisfaction in museums in Thailand. They found that exhibition experience and staff services were positively associated with tourist satisfaction in museums. In addition, Hyun et al. (2018) found out that ambience and aesthetics have important moderating effects on visitors' perceived value and satisfaction in the 
art museum context in Korea. Bideci \& Albayrak (2018) reported that the aesthetic dimension had the highest impact on overall satisfaction of domestic and foreign tourists visiting the Antalya Historical and Archaeological Museum in Turkey. According to Hede et al. (2014), visitor satisfaction in metropolitan and regional museums is affected by perceived authenticity.

\section{RESEARCH DESIGN AND METHODOLOGY}

\subsection{Research framework}

The main purpose of this study was to empirically examine the relationship between service quality and customer satisfaction in the museum sector in Croatia. Specifically, the study intended to answer the following research questions:

1. What is the factor structure of perceived service quality in museums?

2. What is the nature of the relationship between perceived service quality dimensions and overall customer satisfaction in museums?

3. What are the key service quality dimensions that contribute to the museum visitors' satisfaction?

Therefore, the study aimed to (a) identify the main dimensions of perceived service quality in museums, (b) determine the relationship between service quality dimensions and overall customer satisfaction in museums, and (c) discuss the impact of the identified dimensions of perceived service quality on overall customer satisfaction in museums.

Based on the main purpose of the study, the main research hypothesis was proposed as follows:

Hypothesis One (H1): Perceived museum service quality dimensions have a positive and significant effect on overall customer satisfaction.

\subsection{Questionnaire development}

The questionnaire for the research consisted of three parts, designed to measure perceived service quality and customer satisfaction and collect demographic information on the respondents.

The foundation for empirical research was the HISTOQUAL model (Frochot and Hughes, 2000). Based on a literature review the model was modified to meet the specific features of museum service. Item structure included 24 items, selected from studies conducted by Frochot and Hughes (2000) (eleven items), Hui-Ying and Chao-Chien (2008) (ten items), and Martin-Ruiz et al. (2010) (two items). One item was added by the authors (see Appendix 1).

The first part of the questionnaire comprised 24 items aimed to measure perceived museum service quality. Respondents' perceptions were assessed on a 5-point Likert scale, ranging from "strongly disagree" (1) to "strongly agree" (5).

The second part measured museum visitors' satisfaction. This construct was operationalized with one item, representing the overall measure of customer satisfaction. Although some researchers stated that this construct should be measured on the attribute level, thus employing a combination of service attributes, several other researchers used one, overall measure (Yüksel and Rimmington, 1998; Choi and Chu, 2001; Alén Gonzalez et al., 2007; Namkung and Jang, 2008). Therefore, it was 
justified to employ a one-item approach for measuring customer satisfaction in the present study as well. The item was worded "I am satisfied with my museum visit". Overall customer satisfaction was rated on a 5-point Likert scale, ranging from "strongly disagree" (1) to "strongly agree" (5).

The third part of the questionnaire consisted of demographic variables. Respondents' demographic information included age, gender, economic status, level of education, frequency of visiting museums in general, and number of previous visits to the particular museum. These characteristics were measured using a nominal scale.

\subsection{Data collection}

Krapina Neanderthal Museum (Croatia) was selected as the research site for the study. Empirical data were gathered from the museum visitors. Before the data collection started, the museum manager was contacted for permission to conduct the study at the museum. The museum employees helped distribute and collect the questionnaires from the participating visitors. Participation was voluntary. Therefore, the data were collected using a convenience sampling approach. Questionnaires were distributed to the visitors who were willing to participate at the end of their visiting experience. No incentives were provided to the participants.

A total of 250 questionnaires were administered and 116 were returned. Ten questionnaires were eliminated because of incompleteness. Thus, 106 useful questionnaires were obtained, yielding a 42.4 per cent response rate.

\subsection{Data analysis}

Descriptive statistics, exploratory factor analysis, reliability analysis, correlation analysis, and multiple regression analysis were performed to analyse the collected data.

Descriptive statistics was used to examine the demographic profile of the respondents and to evaluate perceived museum service quality and overall customer satisfaction. This study adopted principal component analysis with varimax rotation to determine the factor structure of perceived museum service quality. The Cronbach alpha coefficients were calculated to test the scale's reliability. In addition, multiple regression analysis was conducted to examine the relationship between the combination of perceived museum service quality dimensions and overall customer satisfaction.

\section{RESEARCH RESULTS}

\subsection{Respondents' profile}

First, the demographic profile of the sample is presented in Table 1.

It can be seen that female respondents ( 59.4 per cent) outnumbered male respondents ( 40.6 per cent). In terms of age distribution, about 47 per cent of the respondents were between 16 and 35 years old. Most of the museum visitors in the sample had completed college or university education and slightly less than 40 per cent of the respondents reported they had secondary education. The majority of the respondents had never visited the Krapina Neanderthal Museum before and most of them visit some kind of museum setting on a yearly basis. 
Table 1. Demographic profile of the respondents

\begin{tabular}{lccc}
\hline Items & Percentage & Items & Percentage \\
\hline Gender & & Age & 27.4 \\
Male & 40.6 & $16-25$ & 19.8 \\
Female & 59.4 & $26-35$ & 12.3 \\
& & $36-45$ & 20.8 \\
Level of education & & $46-55$ & 12.3 \\
Primary school & 1.9 & $56-65$ & 7.5 \\
Secondary school & 39.6 & 66 and above & \\
College or university & 55.7 & & 64.2 \\
MSc or PhD & 2.8 & & 23.5 \\
\hline Economic status & & Number of previous visits to the museum \\
\hline Employed & 53.8 & Never & 12.3 \\
Unemployed & 10.4 & Once & \\
Student & 19.8 & Twice or more & \\
Pupil & 2.8 & & \\
Retired & 13.2 & & \\
\hline Frequency of visiting museums (in general) & & \\
\hline 1-2 times per month & 4.7 & & \\
1-2 times per year & 50.0 & & \\
Few times per year & 35.8 & & \\
Other & 9.4 & & \\
\hline
\end{tabular}

Source: Authors

\subsection{Perceived museum service quality dimensions}

As noted in Table 2, the lowest perception item was "access for elderly people and less able visitors" (mean $=3.65$ ) which indicates that according to the visitors' opinion accessibility of the museum is not well customized to the needs of specific groups of visitors. The visitors' highest perceptions were noted regarding new technologies that make the museum visit more interesting $($ mean $=4.83$ ). The overall mean score for service quality perception items was 4.38 . This score indicates very high perceptions of museum visitors regarding service quality.

Table 2. Factor and reliability analyses for perceived museum service attributes

\begin{tabular}{|c|c|c|c|c|c|}
\hline Factors/Items $(n=24)$ & Mean & $\begin{array}{l}\text { Factor } \\
\text { loading }\end{array}$ & Eigen value & $\begin{array}{c}\% \% \text { of } \\
\text { Variance }\end{array}$ & $\begin{array}{c}\text { Cronbach } \\
\text { alpha }\end{array}$ \\
\hline Factor 1 & & & 4.995 & 20.811 & 0.887 \\
\hline V18 - Attractive museum building & $\begin{array}{c}4.15 \\
(1.11)\end{array}$ & 0.829 & & & \\
\hline V19 - Helpful direction signs & $\begin{array}{l}4.53 \\
(0.75)\end{array}$ & 0.788 & & & \\
\hline $\begin{array}{l}\text { V22 - Variety of products in souvenir } \\
\text { shop }\end{array}$ & $\begin{array}{c}3.70 \\
(1.13)\end{array}$ & 0.770 & & & \\
\hline $\begin{array}{l}\text { V20 - Clean environment (interior and } \\
\text { outdoor) }\end{array}$ & $\begin{array}{l}4.64 \\
(0.72)\end{array}$ & 0.727 & & & \\
\hline $\begin{array}{l}\text { V24 - Access for elderly people and less } \\
\text { able visitors }\end{array}$ & $\begin{array}{l}3.65 \\
(1.21)\end{array}$ & 0.666 & & & \\
\hline V21 - Sufficient parking area & $\begin{array}{l}4.42 \\
(0.96)\end{array}$ & 0.655 & & & \\
\hline V23 - Rest rooms provided & $\begin{array}{c}3.77 \\
(1.33)\end{array}$ & 0.617 & & & \\
\hline $\begin{array}{l}\text { V17 - Appropriate position of the info } \\
\text { desk }\end{array}$ & $\begin{array}{c}4.17 \\
(0.91)\end{array}$ & 0.539 & & & \\
\hline
\end{tabular}




\begin{tabular}{|c|c|c|c|c|c|}
\hline Factors/Items $(n=24)$ & Mean & $\begin{array}{c}\text { Factor } \\
\text { loading }\end{array}$ & Eigen value & $\begin{array}{c}\% \text { of } \\
\text { Variance } \\
\end{array}$ & $\begin{array}{c}\text { Cronbach } \\
\text { alpha }\end{array}$ \\
\hline Factor 2 & & & 3.283 & 13.679 & 0.849 \\
\hline $\begin{array}{l}\text { V5 - No restrictions to access (free to } \\
\text { explore) }\end{array}$ & $\begin{array}{c}3.92 \\
(1.15)\end{array}$ & 0.812 & & & \\
\hline V6 - Convenient opening hours & $\begin{array}{c}4.15 \\
(1.01)\end{array}$ & 0.745 & & & \\
\hline V13 - Professional tour guides & $\begin{array}{c}4.18 \\
(0.87)\end{array}$ & 0.646 & & & \\
\hline V4 - Well informed staff & $\begin{array}{l}4.38 \\
(0.76)\end{array}$ & 0.550 & & & \\
\hline V16 - Good info services (info desk) & $\begin{array}{c}4.18 \\
(0.88)\end{array}$ & 0.514 & & & \\
\hline Factor 3 & & & 3.083 & 12.845 & 0.803 \\
\hline $\begin{array}{l}\text { V9 - Educational content of the } \\
\text { exhibition }\end{array}$ & $\begin{array}{c}4.79 \\
(0.41)\end{array}$ & 0.834 & & & \\
\hline $\begin{array}{l}\text { V10 - Attractive content of the } \\
\text { exhibition }\end{array}$ & $\begin{array}{c}4.81 \\
(0.39)\end{array}$ & 0.783 & & & \\
\hline V8 - Foreign language information & $\begin{array}{c}4.72 \\
(0.58)\end{array}$ & 0.555 & & & \\
\hline $\begin{array}{l}\text { V12 - Interesting visit due to new } \\
\text { technologies }\end{array}$ & $\begin{array}{c}4.83 \\
(0.38)\end{array}$ & 0.551 & & & \\
\hline Factor 4 & & & 2.588 & 10.784 & 0.750 \\
\hline $\begin{array}{l}\text { V2 - Willingness to take time with } \\
\text { visitors }\end{array}$ & $\begin{array}{c}4.65 \\
(0.60)\end{array}$ & 0.891 & & & \\
\hline V1 - Helpful and courteous staff & $\begin{array}{c}4.73 \\
(0.53)\end{array}$ & 0.776 & & & \\
\hline $\begin{array}{l}\text { V15 - Understandable mode of guides' } \\
\text { narration }\end{array}$ & $\begin{array}{c}4.32 \\
(0.82)\end{array}$ & 0.476 & & & \\
\hline Factor 5 & & & 2.239 & 9.331 & 0.743 \\
\hline V14 - Audio guides provided & $\begin{array}{c}4.53 \\
(0.77)\end{array}$ & 0.837 & & & \\
\hline V11 - Well explained exhibits & $\begin{array}{c}4.75 \\
(0.48)\end{array}$ & 0.621 & & & \\
\hline V7 - Providing enough information & $\begin{array}{c}4.67 \\
(0.56) \\
\end{array}$ & 0.549 & & & \\
\hline Factor 6 & & & 1.364 & 5.685 & - \\
\hline V3 - Tolerable level of crowding & $\begin{array}{c}4.56 \\
(0.72) \\
\end{array}$ & 0.774 & & & \\
\hline Total & 4.38 & & 17.552 & 73.135 & 0.929 \\
\hline Kaiser-Meyer-Olkin (KMO) & 0.834 & & & & \\
\hline Bartlett's Test of Sphericity & 1800.536 & $0.01)$ & & & \\
\hline
\end{tabular}

Source: Authors

The objective of factor analysis was to identify the main factors of perceived museum service quality, using the principal component method with varimax rotation. The appropriateness for conducting factor analysis was evaluated with the KMO test and Bartlett's test. The KMO value was high, and Bartlett's test was significant, thus the data were suitable to identify the factor structure for the perceived museum service quality scale. The results are reported in Table 2 .

The 24 variables representing museum attributes in this study were reduced to six factors, explaining 73.1 per cent of the total variance in the data. Factor loadings were relatively high, ranging from 0.476 to 0.891 , and indicating reasonably high correlation between items and factors on which they were loaded. 
However, Factor 6 contained only one item and could not be considered as a factor. Thus, the final solution retained five factors that met the rule of thumb for satisfactory factor solution, as suggested by Hair et al. (2010).

After examining the item descriptions, the remaining five factors were interpreted as follows.

Factor 1 ("tangibles") includes eight items referring to museum facilities. Factor 2 ("accessibility") gathered five items reflecting no restrictions for exploring the site, convenient opening hours and available information. Factor 3 ("exhibition presentation") contains four items indicating the presentation features of museum exhibits. Factor 4 ("empathy") is loaded with three items and refers to the staff's readiness to take care of visitors' needs. Finally, Factor 5 ("communication") contains three items and indicates providing professional and detailed information to the visitors.

In addition, the results of the reliability analysis (Table 2) show that Cronbach alpha coefficients of the extracted perception factors range from 0.743 to 0.887 . These values suggest good internal consistency of the factors. Cronbach's alpha value for the overall perceptions scale is 0.929 , and according to Hair et al. (2010) indicates its high reliability.

According to these results, "tangibles", "accessibility", "exhibition presentation", "empathy" and "communication" can be regarded as reliable underlying dimensions of perceived museum service quality.

What is more, Table 3 indicates that visitors to the Krapina Neanderthal Museum perceived "exhibition presentation" as the most dominant perceived service quality dimension (mean $=4.79$ ), followed by "communication" (mean = 4.65), "empathy" (mean = 4.57), "accessibility" (mean $=4.16$ ), and "tangibles" (mean $=4.12)$. The results indicate highly rated museum performance.

\subsection{The relationship between service quality dimensions and overall customer satisfaction in the museum}

As seen in Table 3, the mean score for the overall customer satisfaction item is 4.56, representing a very high level of visitors' overall satisfaction with the museum experience. Additional analysis shows that more than 90 per cent of museum visitors were satisfied or very satisfied with their museum visit.

In order to identify the relative impact of perceived service quality dimensions on overall customer satisfaction, multiple regression analysis was employed. By performing these analyses, the main research hypothesis (H1) was tested.

First, correlation was run to determine the direction of the relationship between the individual perceived museum service quality dimensions and overall visitor satisfaction, as well as to examine the possible multicollinearity of variables in the model.

The correlation matrix (Table 3) indicates that perceived museum service quality dimensions are moderately to strongly correlated with overall customer satisfaction. All the relationships are positive and statistically significant. According to the results, the dimension "tangibles" has the strongest correlation with the dependent variable $(r=0.757, p<0.01)$, followed by "acces- 
sibility", "exhibition presentation", "empathy", and "communication" ( $\mathrm{r}=0.619, \mathrm{r}=0.552, \mathrm{r}=$ 0.496 and $\mathrm{r}=0.382, \mathrm{p}<0.01$, respectively).

Considering that the correlation coefficients reported in Table 3 did not exceed the cut-off value of 0.80, as recommended by Bryman and Cramer (2009), the multicollinearity problem did not emerge in this research, so it was appropriate to continue with multiple regression analysis.

Table 3. Descriptive statistics and correlation matrix

\begin{tabular}{lcccccccc}
\hline \multicolumn{1}{c}{ Variables } & Mean & SD & $\mathbf{1}$ & $\mathbf{2}$ & $\mathbf{3}$ & $\mathbf{4}$ & $\mathbf{5}$ & $\mathbf{6}$ \\
\hline 1. Tangibles* & 4.12 & 0.81 & 1.000 & & & & & \\
2. Accessibility* & 4.16 & 0.76 & 0.609 & 1.000 & & & & \\
3. Exhibition presentation* & 4.79 & 0.36 & 0.544 & 0.560 & 1.000 & & & \\
4. Empathy* & 4.57 & 0.54 & 0.497 & 0.504 & 0.570 & 1.000 & & \\
5. Communication* & 4.65 & 0.50 & 0.323 & 0.410 & 0.579 & 0.508 & 1.000 & \\
6. Overall customer satisfaction** & 4.56 & 0.70 & 0.757 & 0.619 & 0.552 & 0.496 & 0.382 & 1.000 \\
\hline
\end{tabular}

Note: Mean ranges from 1 to $5 ; \mathrm{SD}$ - standard deviation; * - independent variable; ** - dependent variable; all correlation coefficients are significant at 0.01 level.

Source: Authors

Table 4. Multiple regression analysis

\begin{tabular}{lcccc}
\hline Model fit & & & & \\
\hline Multiple R & 0.792 & & & \\
$\mathrm{R}^{2}$ & 0.627 & & & \\
Adjusted R & & & \\
Standard error & 0.609 & & & \\
$F$-ratio & 0.440 & & & \\
Significance & 33.661 & & $\mathbf{~}$ & Sig. \\
\hline Independent variable & 0.000 & & 0.689 & 0.492 \\
\hline Constant & $\mathbf{b}$ & Beta & 6.710 & $0.000^{*}$ \\
Tangibles & 0.417 & & 2.212 & $0.029^{* *}$ \\
Accessibility & 0.481 & 0.554 & 0.984 & 0.328 \\
Exhibition presentation & 0.170 & 0.185 & 0.634 & 0.527 \\
Empathy & 0.174 & 0.088 & 0.647 & 0.519 \\
Communication & 0.067 & 0.051 & & \\
\hline
\end{tabular}

Note: Dependent variable: overall customer satisfaction; * - significant at 0.01 level; ** - significant at 0.05 level.

Source: Authors.

As shown in Table 4, the results of multiple regression analysis reveal the following. The relationship between the combination of independent variables in the model and the dependent variable is strong $(R=0.792)$. According to the coefficient of determination $\left(R^{2}=0.627\right)$ and adjusted coefficient of determination (adjusted $\mathrm{R}^{2}=0.609$ ), the five perceived museum service quality dimensions explain approximately 61 per cent of variance in overall customer satisfaction. In addition, the significant $F$-ratio $(\mathrm{F}=33.661, \mathrm{p}<0.01)$ suggests that results of the adopted regression model could have not occurred by chance and that the combination of independent variables significantly predicted the dependent variable.

To assess the relative importance of each independent variable in determining the value of the dependent variable, beta coefficients are provided. According to Table 4, two out of five inde- 
pendent variables significantly influence overall customer satisfaction. The dimension "tangibles" $(\beta=0.554, p<0.01)$ has the highest statistically significant standardized coefficient. Therefore, this is the most important independent variable and has the highest impact on overall customer satisfaction. It is followed by the dimension "accessibility" $(\beta=0.185, p<0.05)$. The dimensions "exhibition presentation", "empathy", and "communication" have a small impact on overall customer satisfaction and are not statistically significant $(\beta=0.088, \beta=0.051, \beta=0.051$, $\mathrm{p}>0.05$, respectively).

\section{CONCLUSION}

The present research was designed to empirically examine the nature of the relationship between perceived service quality dimensions and overall customer satisfaction in the museum sector in Croatia.

The findings of factor analysis reveal that the main dimensions of perceived museum service quality in Croatia are "tangibles", "accessibility", "exhibition presentation", "empathy" and "communication". These findings are somewhat consistent with similar studies conducted in the museum sector. Hui-Ying and Chao-Chien (2008) reported a five-factor structure for perceived service quality, labelled as "educational entertainment", "responsiveness and assurance", "reliability", "tangibility" and "convenience".

Multiple regression analysis indicated that perceived museum service quality is an important antecedent of overall customer satisfaction, confirming the main study hypothesis (H1). This finding can be compared with the results of similar studies conducted in the museum sector in Poland (Nowacki, 2005), South Africa (Radder and Han, 2013), Macau (Wu and Li, 2015), and Thailand (Duantrakoonsil and Reid, 2017).

Furthermore, the indicators of multiple regression analysis in this study reveal a strong, positive and significant relationship between the combination of perceived museum service quality dimensions and overall customer satisfaction, implying that highly perceived "tangibles", "accessibility", "exhibition presentation", "empathy" and "communication" lead to higher overall visitor satisfaction in the Croatian museum sector. Additionally, approximately 61 percent of variance in overall customer satisfaction can be explained by these dimensions, suggesting that the explanatory power of the tested model in the museum sector is satisfactory.

The most important predictor of overall customer satisfaction in this study is the dimension "tangibles". Therefore, an attractive museum building, clean environment (interior and outdoor), sufficient parking area, rest rooms, variety of souvenirs, and appropriate signage have the greatest impact on overall museum visitor satisfaction.

Furthermore, "accessibility" turned out to be the second most important dimension affecting overall customer satisfaction in this study. Hence, convenient opening hours, no restrictions for exploring the site, and available information affect overall customer satisfaction.

Although Pearson's correlation coefficients between the dimensions "exhibition presentation", "empathy" and "communication" on the one hand and overall customer satisfaction on the other implied significant positive correlation, when two other dimensions were involved in the model, these dimensions did not have a statistically significant impact on overall customer satisfaction. 
Nevertheless, the combination of the five perceived museum service quality dimensions tested in this study demonstrates a significant impact on overall customer satisfaction. The findings confirm that improved tangibles, accessibility, exhibition presentation, empathy, and communication enhance overall customer satisfaction in museums. Therefore, museum managers should set priorities and continue to improve these important aspects of museum service quality.

Based on the presented findings, the authors believe that the present study provides reliable and comprehensive information for both academics and practitioners. Theoretically, the study contributes to the existing literature on museum service quality and customer satisfaction relationship, reporting the findings from the Croatian museum sector, which is presently an under-researched area. The measurement scale for perceived museum service quality is based on the HISTOQUAL methodology and is modified to be applicable for museums as specific heritage sites. According to the reliability analysis, the modified scale is highly reliable, thus representing a valuable and reliable instrument for measuring service quality in the museum sector. Since the measurement instrument was developed in accordance with other studies in the heritage context, the results are suitable for broader international comparisons. What is more, the methodology could be applied to other types of cultural and heritage sites in different tourist destinations.

In addition, as mentioned previously, this study has practical implications as well. Museum managers should monitor visitors' perceptions of museum service quality to maximize visitor satisfaction in the museum. Particularly, to increase the level of museum visitors' satisfaction museum managers should focus on ensuring the excellence of exhibition presentation and service accessibility that are provided by empathetic and competent staff in visually appealing and appropriately fitted facilities. According to the results, although the tangible factor of museum service has an important role in enhancing museum visitors' satisfaction, intangible aspects are appreciated by museum visitors as well.

This study has several limitations that should be mentioned. Firstly, the study was conducted in only one museum. The application of the study in other museums would ensure more comprehensive results. In addition, in order to identify visitors' opinions of different museums, the sample should include different types of museums (e.g. art, lifestyle, history, religion, children's museums). Secondly, although the set of museum service attributes included in the study covered a variety of museum service aspects, there could be other relevant items that are likely to influence museum visitors' satisfaction. In future research, the museum service attribute structure could be broadened with specific aspects of museum service, when conducting the study in specific types of museums. Additionally, potential differences in the service quality and customer satisfaction relationship could emerge between domestic and foreign museum visitors, local and non-local visitors, as well as between young visitors and other generations. Thus, future research should also address these differences. 


\section{REFERENCES}

Alén González, M. E. A., Comesana, L. R., \& Brea, J. A. F. (2007). Assessing tourist behavioral intentions through perceived service quality and customer satisfaction. Journal of Business Research, 60, 153-160.

Bideci, M., \& Albayrak, T. (2018). An investigation of the domestic and foreign tourists' museum visit experiences. International Journal of Culture, Tourism and Hospitality Research, 12(3), 366-377, DOI 10.1108/IJCTHR-02-2018-0029.

Bryman, A., \& Cramer, D. (2009). Quantitative Data Analysis with SPSS 14, 15 and 16: A Guide for Social Scientists. London, New York: Routledge.

Choi, T. Y., \& Chu, R. (2001). Determinants of hotel guests' satisfaction and repeat patronage in the Hong Kong hotel industry. International Journal of Hospitality Management, 20, 277-297.

Duantrakoonsil, T., \& Reid, E. L. (2017). Museum Service Quality, Satisfaction, and Revisit Intention: Evidence from the Foreign Tourists at Bangkok National Museums in Thailand. Culinary Science \& Hospitality Research, 23(6), 127- 134.

Fornell, C. (1992). A National Customer Satisfaction Barometer: The Swedish Experience. Journal of Marketing, 56, 6-21.

Frochot, I., \& Hughes, H. (2000). HISTOQUAL: The development of a historic houses assessment scale. Tourism Management, 21(2), 157-167.

Gilmore, A., \& Rentschler, R. (2002). Changes in Museum Management: A Custodial or Marketing Emphasis? Journal of Management Development, 20(10), 745-760.

Hair, J. F., Black, W. C., Babin, B. J., \& Anderson, R. E. (2010). Multivariate Data Analysis: A Global Perspective. 7th Edition, New Jersey: Pearson Education Inc, Upper Saddle River.

Harrison, P., \& Shaw, R. (2004). Consumer satisfaction and post-purchase intentions: An exploratory study of museum visitors. International Journal of Arts Management, 6(2), 23-33.

Hede, A.-M., Garma, R., Josiassen, A., \& Thyne, M. (2014). Perceived authenticity of the visitor experience in museums: Conceptualization and initial empirical findings. European Journal of Marketing, 48(7/8), 1395-1412, DOI 10.1108/EJM-12-2011-0771.

Hui-Ying, S., \& Chao-Chien, C. (2008). A Study of Service Quality and Satisfaction for Museums - Taking the National Museum of Prehistory as an Example. The Journal of Human Resource and Adult Learning, 14(1), 159-170.

Hyun, H., Park, J., Ren, T., \& Kim, H. (2018). The role of ambiences and aesthetics on millennials' museum visiting behaviour. Arts and the Market, 8(2), 152-167, DOI 10.1108/AAM04-2017-0006.

Kozak, M., \& Remmington, M. (2000). Tourist Satisfaction with Mallorca, Spain, as an Off-Season Holiday Destination. Journal of Travel Research, 38, 260-269.

Martin-Ruiz, D., Castellanos-Verdugo, M., \& Oviedo-Garcia, M. (2010). A visitors' evaluation index for a visit to an archaeological site. Tourism Management, 31, 590-596.

Mey, L. P., \& Mohamed, B. (2010). Service quality, visitor satisfaction and behavioural intentions: pilot study at a museum in Malaysia. Journal of Global Business and Economics, 1(1), 226-240.

Namkung, Y., \& Jang, S. (2008). Are highly satisfied restaurant customers really different? A quality perception perspective. International Journal of Contemporary Hospitality Management, 20(2), 142-155.

Nowacki, M. M. (2005). Evaluating a museum as a tourist product using the SERVQUAL method. Museum Management and Curatorship, 20(3), 235-250.

Oliver, R. L. (1997). Satisfaction: A Behavioral Perspective on the Consumer. New York, NY: McGraw-Hill. 
Phaswana-Mafuya, N., \& Haydam, N. (2005). Tourists' expectations and perceptions of the Robben Island Museum - a world heritage site. Museum Management and Curatorship, 20(2), 149-169.

Pop, I. L., \& Borza, A. (2016). Quality in Museums as a Way to Increase Sustainability. European Journal of Sustainable Development, 5(3), 217-228.

Radder, L., \& Han, X. (2013). Perceived Quality, Visitor Satisfaction, And Conative Loyalty In South African Heritage Museums. International Business Economics Research Journal, 12(10), 1261-1272.

Radder, L., Han, X., \& Hou, Y. (2011). An integrated evaluation of the heritage museum visit: a disconfirmation approach. International Journal of Management Cases, 13(3), 315-326.

Wu, H. C., \& Li, T. (2015). An Empirical Study of the Effects of Service Quality, Visitor Satisfaction, and Emotions on Behavioral Intentions of Visitors to the Museum of Macau. Journal of Quality Assurance in Hospitality \& Tourism, 16(1), 80-102, DOI: 10.1080/1528008X.2015.966298.

Yüksel, A., \& Rimmington, M. (1998). Customer-Satisfaction Measurement. The Cornell Hotel and Restaurant Administration Quarterly, December, 60-70.

\section{APPENDIX 1: MUSEUM SERVICE ATTRIBUTES INCLUDED IN THIS STUDY}

\section{Museum service attributes}

V1 - Helpful and courteous staff

V2 - Willingness to take time with visitors

V3 - Tolerable level of crowding

V4 - Well informed staff

V5 - No restrictions to access (free to explore)

V6 - Convenient opening hours

V7 - Providing enough information

V8 - Foreign language information

V9 - Educational content of the exhibition

V10 - Attractive content of the exhibition

V11 - Well explained exhibits

V12 - Interesting visit due to the new technologies

V13 - Professional tour guides

V14 - Audio guides provided

V15 - Understandable mode of guides' narration

V16 - Good info services (info desk)

V17 - Appropriate position of the info desk

V18 - Attractive museum building

V19 - Helpful direction signs

V20 - Clean environment (interior and outdoor)

V21 - Sufficient parking area

V22 - Variety of products in souvenir shop

V23 - Rest rooms provided

V24 - Access for elderly people and less able visitors

\section{Source}

Frochot, Hughes (2000)

Frochot, Hughes (2000)

Frochot, Hughes (2000)

Frochot, Hughes (2000)

Frochot, Hughes (2000)

Frochot, Hughes (2000)

Frochot, Hughes (2000)

Frochot, Hughes (2000)

Hui-Ying, Chao-Chien (2008)

Hui-Ying, Chao-Chien (2008)

Martin-Ruiz et al. (2010)

Martin-Ruiz et al. (2010)

Hui-Ying, Chao-Chien (2008)

Authors

Hui-Ying, Chao-Chien (2008)

Hui-Ying, Chao-Chien (2008)

Hui-Ying, Chao-Chien (2008)

Frochot, Hughes (2000)

Frochot, Hughes (2000)

Hui-Ying, Chao-Chien (2008)

Hui-Ying, Chao-Chien (2008)

Hui-Ying, Chao-Chien (2008)

Hui-Ying, Chao-Chien (2008)

Frochot, Hughes (2000) 